\title{
우수유출저감용 저류지의 간편설계기법 개발 \\ A Development of Simplified Design Method of the Detention Pond for the Reduction of Runoff
}

\author{
이 재 준 ${ }^{*}$ 곽 창 재 ${ }^{* *}$
}

Lee, Jae Joon / Kwak, Chang Jae

\begin{abstract}
Detention pond has an important role in peak flow reduction to mitigate flood damage. Design of detention pond is accomplished through the preliminary stage, and design stage in general. New development projects produce increased peak flow and flow amounts. In this case it is necessary to design the detention pond easily and simply. A simplified design method of the detention pond is suggested in this study. Used design variables are peak flow ratio $(\alpha)$ and storage $\operatorname{ratio}\left(S_{r}\right) . \alpha$ is the peak flow ratio of before and after development of the basin. $S_{r}$ is a ratio of storage volume to total runoff volume. Applicability of the proposed method was also proved. The simple procedure of detention pond design is proposed in this study.
\end{abstract}

keywords : Detention Pond, Peak Flow Ratio, Reduction of Runoff, Simplified Design Method, Storage ratio

\section{요 지}

저류지를 설계함에 있어서 주어진 저류지 제원과 방류시설 제원하에서 저류지 설계모의모형을 이용하여 저류추적 을 실시하는 방법을 대치하고자 저류지의 예비설계 단계에서 저류지 최적계획모형에 의해 산정된 저류용량을 초기 가정치로 사용하거나 개발전후의 첨두유량비인 $\alpha$ 를 사용하여 저류지를 간편설계하기 위한 관련변수 해석을 실시하 였다. 관련변수 해석을 통해 저류지의 유입첨두유량에 대한 저류지 첨두방류량의 비인 첨두유량비 $\alpha$ 와 저류지의 저 류비 $S_{r}$, 저류지의 방류구조 크기 $\mathrm{D}$ 와 저류지의 최대허용수심 $H_{\max }$, 저류지의 구형바닥면적 $\mathrm{A}^{\prime}$ 과 저류지의 제형바 닥면적 $\mathrm{A}$ 및 $A_{c}$ 의 관계를 이용하여 저류지를 간편하게 설계하는 간편설계기법의 절차를 제시하였다. 저류지의 간편 설계기법은 도시화로 인한 유출총량 및 첨두유량 증대에 대처하는 방안으로 도시유역에서 유출저감시설로서 신설되 는 저류지를 설계함에 있어서 기존의 많은 제반사항과 저류지 추적을 시행하지 않고 간편한 설계를 할 수 있는 방법 으로 활용가능하다.

핵심용어 : 유출저감효과, 저류지, 첨두유량비, 저류비, 간편설계기법

\footnotetext{
* 국립금오공과대학교 토목환경공학부 교수

Professor, Dept. of Civil and Environmental Engrg., Kumoh National Institute of Technology,

1 Yangho-dong, Gumi, Gyeongbuk 730-701, Korea

(e-mail: jhb365@kumoh.ac.kr)

** 국립금오공과대학교 대학원 토목공학과 박사과정

Ph.D. candidate, Dept. of Civil and Environmental Engrg., Kumoh National Institute of Technology,

1 Yangho-dong, Gumi, Gyeongbuk 730-701, Korea
} 


\section{1. 서 론}

저류지를 설계 운영함에 있어서 사용되는 모형은 일 반적으로 계획모형(planning model), 설계모형(design model) 및 운영모형(operation model)으로 분류되고 있 다. 기초계획 단계에서는 저류지의 홍수조절효과를 산 정할 때 엄밀하게 계산하는 것이 꼭 효율이 좋다고 할 수 없으며, 또한 최적설계를 하는 데는 많은 시간이 소 요된다. 따라서 저류지의 계획단계에서는 기존의 복잡 하고 지루한 과정을 거치지 않고 저류지의 적정용량과 설계인자를 도출할 수 있는 저류지 관련 인자들의 상호 분석을 통한 설계도표의 마련과 간편설계기법 개발이 필요하다.

국외의 연구동향을 살펴보면 저류지 설계기법에 관 련해서 Guo et al.(1999)은 저류지 설계에 이용되는 확 률해석기법을 이용한 저류지 계획 및 설계기법을 제시 하였고, Guo(2001)는 저류지의 일반적인 수문학적 설계 기법인 설계호우기법, 연속모의기법, 확률해석기법을 가 상유역에 적용하여 비교하였고, 확률해석기법에 관한 적합성을 입증하였다.

국내의 저류지 관련 연구동향을 연도별로 살펴보면 윤여진 등(2001)은 저류비의 개념을 이용하여 산정된 저류지 용량과 강우지속기간에 따른 저류지의 최대 용 적을 비교, 분석하여 저류지 설계시 적정용량 산정 방 법을 제안하였고, 안태진 등(2003)은 소규모 배수구역에 서 조정지용량의 결정시 펌프의 계획배수량과 유수지 용량에 따른 펌프의 시동빈도를 반영하여 기존의 최대 저류지에 의한 방법을 개선한 방안을 제시하였고, 신응 배 등(2003)은 SWMM모형을 이용하여 설계강우에 대 한 적정저류용량을 산정하였다. 이처럼 도시지역에서의 유수지 효과와 유수지를 통한 저감효과분석 및 저류시 설의 용량결정 등에 관한 연구를 수행한 바 있지만, 저 류지의 설계기법에 관한 사항은 미흡한 실정이다.

따라서 저류지 관련 인자들의 상호분석과 설계모의 모형과의 적합성 검증 연구 성과를 통해(이재준 등, 2006 a,b) 저류지 설계에 필요한 도표를 도출하고, 실무 에서 이용 가능한 저류지의 간편설계기법을 제시함으로 써 기존의 복잡하고 지루한 과정을 거치지 않고 계획단 계에서 저류지의 적정용량과 설계인자에 대한 사항을 보다 쉽게 얻고자 한다.

\section{2. 저류지 간편설계를 위한 관련변수 해석}

일반적으로 저류지를 설계함에 있어서는 강우-유출 해석을 실시하여 유역의 유출총량을 산정한 후 개발전
후의 첨두유량의 차와 저류지의 유입유량에 따라 저류 용량을 결정하게 되며, 저류지의 수심-저류용량 관계, 수심-방류량 관계를 제시할 수 있는 방류시설의 종류 와 제원, 저류지 바닥 및 상부면적, 저류지의 깊이 등 이 결정됨으로써 설계가 완료된다. 저류지 설계에 관 련된 인자들은 유역 특성인자, 수문 특성인자가 있으 며, 본 연구에 앞서 도시유역에서 저류지설계를 위한 특성인자 분석(이재준 등, $2006 \mathrm{~b}$ )을 통해 저류지 설계 에 있어서는 첨두유량비 $\alpha$, 저류비 $S_{r}$ 이 중요한 요소 로 나타났다. 이에 본 연구에서는 저류지 설계관련 인 자들간의 관련변수 해석을 위해 설계모의모형을 이용 하여 case 1 case 13의 13가지 모의조건을 선정하여 변경시키면서 예비설계 단계에서 주어진 저류용량과 개발전 첨두유량을 충족시키는 저류지 및 방류시설의 제원을 산출하였다.

저류지를 설계함에 있어서 주어진 저류지 제원과 방 류시설 제원하에서 저류지 설계모의모형을 이용하여 저 수지홍수추적을 실시하는 방법을 대치하고자 저류지의 예비설계 단계에서 저류지 최적계획모형에 의해 산정된 저류용량을 초기가정치로 사용하거나 개발전후의 첨두 유량비인 $\alpha$ 를 사용하여 저류지를 간편설계하기 위한 관련변수 해석을 실시하였다.

\section{1 저류지 간편설계기법 관련변수 선정을 위한 모의조건 및 가정사항}

국내 저류지의 설계강우 임계지속기간은 대체로 4 0 230분 정도로 나타나고 있으며(행정자치부, 2000 2006) 도시유역에서 첨두유량 발생시각은 대략 2 시간이 내에 있으므로 저류지의 유입수문곡선은 첨두유량 발생 시간 $\left(t_{p}\right)$ 은 2 시간, 기저시간 $\left(T_{b}\right)$ 은 $3 t_{p}$ 로 설정하여 6 시 간으로 그려지는 Fig. 1과 같은 삼각형 수문곡선형태로 가정하고 유입첨두유량은 2000년이래로 수행된 재해영 향평가서의 유입첨두유량의 범위 $3.62 \sim 114.8 \mathrm{~m}^{3} / \mathrm{s}$ 중 $3 \sim 60 \mathrm{~m}^{3} / \mathrm{s}$ 의 범위의 값을 사용하였다. 이 때 방류구조 는 오리피스(유량계수 $\mathrm{C}=0.65$ )로 한정하고 방류구의 위 치는 하수도설계기준(환경부, 2005)에서 명시하고 있는

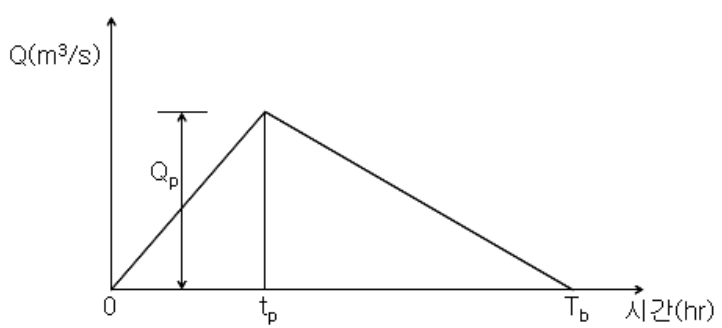

Fig. 1. Inflow Hydrograph for Development of Simplified Design Method 


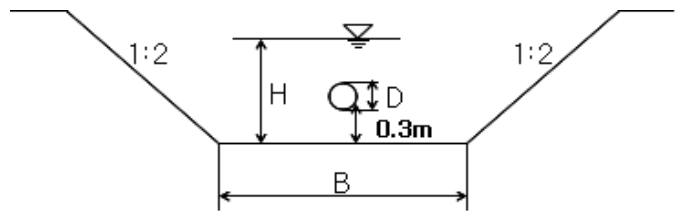

단 면 도

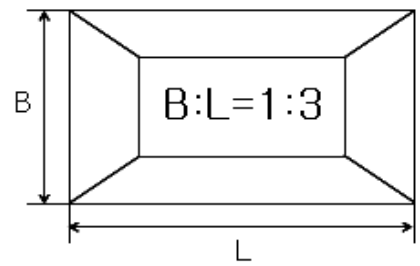

평 면 도

Fig. 2. Cross Section and Plane Figure of Detention Pond

퇴사위 $30 \mathrm{~cm}$ 이상을 기준으로 택하여 저류지 바닥면에 서 $30 \mathrm{~cm}$ 에 위치하는 것으로 설정하였다. 저류지의 형태 는 소방방재청과 한국방재협회(2005)의 “재해영향평가 실무지침서 개정” 상의 영구저류지 설계기준인 폭과 길 이의 비가 1:3, 사면경사 1:2인 사다리꼴로 가정하였다. Fig. 2 는 재해영향평가서에서 규정한 저류지의 단면도 및 평면도를 도시한 것이다.

Table 1은 저류지의 간편설계기법 관련변수 선정을 위한 수치모의조건을 수록한 것이다. 유입첨두유량, 유 입총량, 방류구 직경범위, 저류지 유효수심범위, 구형저 류지 바닥면적, 저류용량 등을 바탕으로 case1 case13의 모의조건을 선정한 후 설계모의모형인 BASINOPT모형(Paine, 1998)을 이용하여 저류지 설계
를 실시하였다.

BASINOPT 모형은 저류지의 요구 수면적과 용량을 최소화하는 작업을 수행할 수 있고, 저류지의 형태를 최적화 할 수 있으며, 호우사상에 대하여 최대 허용 수 면적과 유량에 대한 방류구 구조물의 배치를 할 수 있 는 설계모의모형이다. BASINOPT 모형은 시뮬레이션 모드를 가지고 있어서, 사용자가 저류지의 형태나 구조 물의 배치 또는 수위-면적-유량관계를 직접 이용할 수 있다. BASINOPT 모형의 기술적 바탕은 Akan(1993), Brater and King(1996), 그리고 FHWA의 Culvert Manual에 두고 있다.

Table 2는 모의조건별 즉, 가정 유입첨두유량별 방류 구 직경의 변화에 따른 저류지 최적설계의 결과를 나타 낸 것이다. 여기서 $Q_{i p}$ 는 개발후 유입첨두유량, $Q_{o p}$ 는 첨두방류량(=개발전 유입첨두유량), $V_{\text {smax }}$ 는 최대저류 용량, $H_{\max }$ 는 최대저류수심, $\mathrm{D}$ 는 방류구의 직경, $\alpha$ 는 첨두유량비, $S_{r}$ 은 저류비 $\left(=V_{s \max } / Q_{a}\right), Q_{a}$ 는 개발후 유 입수문곡선의 총유출량, $\mathrm{A}^{\prime}$ 은 구형(矩形)저류지 바닥면 적 $\left(=V_{\text {smax }} / H_{\max }\right)$ 을 나타낸다.

\section{2 저류지 간편설계기법을 위한 관련변수 해석}

본 절에서는 계획단계에서 이용할 수 있는 저류지의 간편설계기법을 제시하고자 저류지 설계모의모형을 통 해 도출된 최적 설계결과(Table 2)를 이용하여 저류지 설계 관련변수인 첨두유량비 $(\alpha)$ 와 저류비 $\left(S_{r}\right)$, 방류구 직경 $(\mathrm{D})$, 저류지 최대허용수심 $\left(H_{\max }\right)$, 저류지 바닥면적 의 관계 등을 분석하였다.

Table 1. Simulation Cases for Parameter Selection of Simplified Design Method

\begin{tabular}{|c|c|c|c|c|c|c|}
\hline 모의조건 & $\begin{array}{c}\text { 유입첨두유량 } \\
\left(\mathrm{m}^{3} / \mathrm{s}\right)\end{array}$ & $\begin{array}{c}\text { 유입총량 } \\
\left(\mathrm{m}^{3}\right)\end{array}$ & $\begin{array}{c}\text { 방류구 } \\
\text { 직경범위 }(\mathrm{m})\end{array}$ & $\begin{array}{c}\text { 저류지 유효 } \\
\text { 수심범위 }(\mathrm{m})\end{array}$ & $\begin{array}{c}\text { 구형저류지 } \\
\text { 바닥면적 }\left(\mathrm{m}^{2}\right)\end{array}$ & $\begin{array}{c}\text { 저류용량 } \\
\left(\mathrm{m}^{3}\right)\end{array}$ \\
\hline Case 1 & 3 & 32,400 & $0.7 \sim 1.2$ & $1.5 \sim 4.0$ & $1,000 \sim 2,500$ & $2,000 \sim 9,000$ \\
\hline Case 2 & 6 & 64,800 & $1.0 \sim 1.6$ & $2.0 \sim 5.0$ & $1,000 \sim 3,500$ & $4,000 \sim 12,000$ \\
\hline Case 3 & 10 & 108,000 & $1.3 \sim 2.0$ & $2.0 \sim 5.5$ & $1,500 \sim 3,000$ & $4,000 \sim 15,000$ \\
\hline Case 4 & 15 & 162,000 & $1.5 \sim 2.4$ & $2.5 \sim 7.0$ & $1,500 \sim 7,000$ & $5,000 \sim 22,000$ \\
\hline Case 5 & 20 & 216,000 & $1.8 \sim 2.7$ & $3.0 \sim 7.0$ & $1,500 \sim 4,000$ & $6,000 \sim 21,000$ \\
\hline Case 6 & 25 & 270,000 & $2.0 \sim 3.0$ & $3.0 \sim 7.0$ & $1,500 \sim 4,000$ & $6,000 \sim 23,000$ \\
\hline Case 7 & 30 & 324,000 & $2.2 \sim 3.2$ & $3.0 \sim 7.5$ & $2,000 \sim 6,000$ & $8,000 \sim 24,000$ \\
\hline Case 8 & 35 & 378,000 & $2.4 \sim 3.4$ & $3.5 \sim 7.0$ & $2,000 \sim 6,000$ & $8,000 \sim 24,000$ \\
\hline Case 9 & 40 & 432,000 & $2.5 \sim 3.6$ & $3.5 \sim 8.0$ & $2,000 \sim 5,500$ & $8,000 \sim 28,000$ \\
\hline Case 10 & 45 & 486,000 & $2.7 \sim 3.7$ & $4.0 \sim 7.5$ & $2,000 \sim 7,000$ & $11,000 \sim 27,000$ \\
\hline Case 11 & 50 & 540,000 & $2.8 \sim 3.9$ & $4.0 \sim 8.0$ & $2,000 \sim 4,000$ & $10,000 \sim 29,000$ \\
\hline Case 12 & 55 & 594,000 & $3.0 \sim 4.1$ & $4.0 \sim 8.0$ & $2,000 \sim 8,500$ & $12,000 \sim 35,000$ \\
\hline Case 13 & 60 & 648,000 & $3.1 \sim 4.2$ & $4.0 \sim 8.0$ & $2,000 \sim 8,000$ & $13,000 \sim 34,000$ \\
\hline
\end{tabular}


Table 2. Reselts of Detention Pond Design by Case

\begin{tabular}{|c|c|c|c|c|c|c|c|c|c|c|c|c|c|}
\hline $\begin{array}{c}\text { 모의 } \\
\text { 조건 }\end{array}$ & 1 & 2 & 3 & 4 & 5 & 6 & 7 & 8 & 9 & 10 & 11 & 12 & 13 \\
\hline $\mathrm{Q}_{\mathrm{ip}}\left(\mathrm{m}^{3} / \mathrm{s}\right)$ & 3 & 6 & 10 & 15 & 20 & 25 & 30 & 35 & 40 & 45 & 50 & 55 & 60 \\
\hline $\mathrm{Q}_{\mathrm{a}}\left(\mathrm{m}^{3}\right)$ & 32,400 & 64,800 & 108,000 & 162,000 & 216,000 & 270,000 & 324,000 & 378,000 & 432,000 & 486,000 & 540,000 & 594,000 & 648,000 \\
\hline $\mathrm{Q}_{\mathrm{op}}\left(\mathrm{m}^{3} / \mathrm{s}\right)$ & 2.785 & 5.604 & 9.688 & 13.965 & 19.56 & 24.623 & 28.991 & 33.796 & 39.041 & 42.978 & 49.045 & 52.842 & 57.607 \\
\hline $\mathrm{V}_{\mathrm{smax}}\left(\mathrm{m}^{3}\right)$ & $3,462.0$ & $6,164.6$ & $6,297.8$ & $18,300.3$ & $10,281.0$ & $11,829.7$ & $19,721.4$ & $21,608.3$ & $19,347.3$ & $26,689.2$ & $16,319.4$ & $34,622.6$ & $33,256.3$ \\
\hline $\mathrm{H}_{\max }(\mathrm{m})$ & 1.631 & 2.037 & 2.447 & 2.65 & 3.058 & 3.264 & 3.468 & 3.671 & 3.875 & 4.077 & 4.283 & 4.283 & 4.486 \\
\hline $\mathrm{D}(\mathrm{m})$ & 1.2 & 1.6 & 2.0 & 2.4 & 2.7 & 3.0 & 3.2 & 3.4 & 3.6 & 3.7 & 3.9 & 4.1 & 4.2 \\
\hline $\mathrm{A}\left(\mathrm{m}^{2}\right)$ & 1,516 & 2,000 & 1,577 & 4,080 & 1,848 & 1,922 & 2,913 & 2,913 & 2,390 & 3,031 & 1,707 & 3,623 & 3,217 \\
\hline$\alpha$ & 0.928 & 0.934 & 0.969 & 0.931 & 0.978 & 0.985 & 0.966 & 0.966 & 0.976 & 0.955 & 0.981 & 0.961 & 0.960 \\
\hline$S_{r}$ & 0.107 & 0.095 & 0.058 & 0.113 & 0.048 & 0.044 & 0.061 & 0.057 & 0.045 & 0.055 & 0.030 & 0.058 & 0.051 \\
\hline $\mathrm{A}^{\prime}\left(\mathrm{m}^{2}\right)$ & $2,122.6$ & $3,026.3$ & $2,573.7$ & $6,905.8$ & $3,362.0$ & $3,624.3$ & $5,686.7$ & $5,886.2$ & $4,992.8$ & $6,546.3$ & $3,810.3$ & $8,083.7$ & $7,413.3$ \\
\hline
\end{tabular}

2.2.1 첨두유량비와 저류비 관계도

모의조건별로 가정사항을 이용하여 13 가지 경우에 대한 저류지 최적설계결과를 이용하여 저류비 $S_{r}$ 에 대 한 첨두유량비 $\alpha$ 간의 관계곡선을 작성하여 Fig. 3에 수 록하였다. Table 3은 Fig. 3의 관계에 대한 회귀식을 수 록한 것이다.

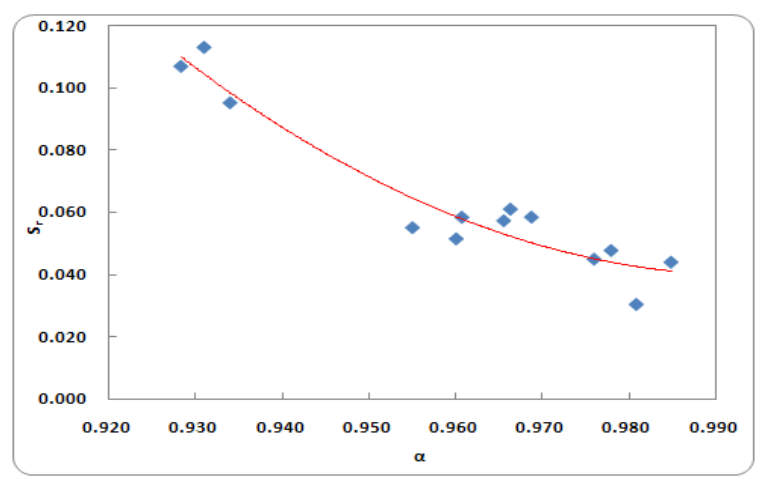

Fig. 3. Relationship between $a$ and $\mathrm{S}_{\mathrm{r}}$

Table 3. Relationship between $a$ and $\mathrm{S}_{\mathrm{r}}$

\begin{tabular}{|c|cc|c|}
\hline 구 분 & 회 귀 식 & 결정계수 $\left(\mathrm{R}^{2}\right)$ \\
\hline $\begin{array}{c}\text { 첨두유량비 } \alpha \text { 에 } \\
\text { 대한 저류비 } S_{r}\end{array}$ & \multicolumn{2}{|c|}{$\begin{array}{c}\text { S } \\
S_{r}=16.031\end{array}$} & 0.859 \\
\hline
\end{tabular}

Fig. 3에서 보면 저류비 $S_{r}$ 과 첨두유량비 $\alpha$ 의 관계 는 서로 반비례 관계를 보여주고 있으며 개발후 유입첨 두유량과 개발전 유입첨두유량을 이용하여 첨두유량비 $\alpha$ 가 구해지면 저류비를 Fig. 3으로부터 구할 수 있고, 저류비의 정의식을 이용하여 유출총량으로부터 저류용 량을 결정할 수 있다.
2.2.2 방류구 크기에 대한 저류지의 최대수심 관계도 본 절에서는 설계 초기의 가정사항이 될 수 있는 저 류지의 방류시설의 크기에 대한 개발전 유입첨두유량 (첨두방류량, $Q_{o p}$ )의 관계도를 작성하여 Fig. 4 에 수록 하였다. 즉, 방류구 직경 초기치를 설정할 수 있도록 첨 두방류량에 따라 방류구 직경과 첨두방류량의 관계를 도시한 것으로서 Fig. 4에서 보면 2차 함수식으로 상호 비례하고 있음을 알 수 있다. Fig. 4는 방류구의 직경 을 택하는 기준으로서 첨두방류량을 사용 할 수 있음을 시사해주고 있다. Table 4는 Fig. 4의 관계에 대한 회귀 식을 수록한 것으로서 결정계수 0.993 의 아주 높은 관 련성을 보여주고 있다.

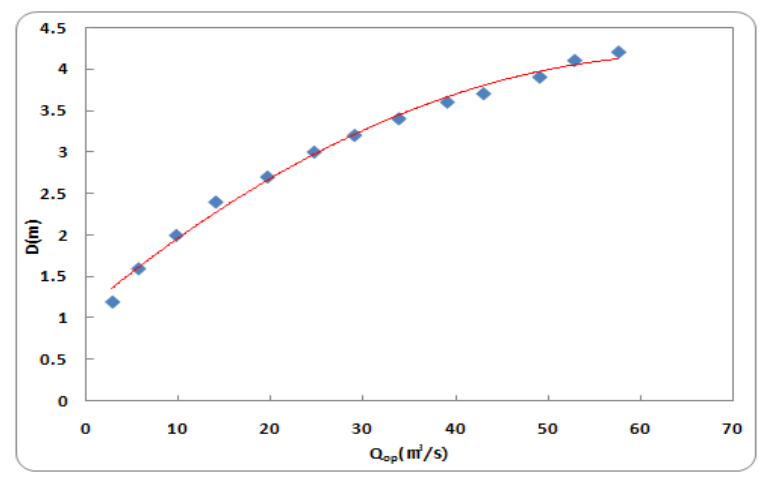

Fig. 4. Relationship between $Q_{o p}$ and D

Table 4. Relationship between $Q_{o p}$ and D

\begin{tabular}{|c|c|c|}
\hline 구 분 & 회 귀 식 & 결정계수 $\left(\mathrm{R}^{2}\right)$ \\
\hline $\begin{array}{c}\text { 저류지 첨두방류량 } \\
Q_{o p} \text { 에 대한 } \\
\text { 방류구 직경 } \mathrm{D}\end{array}$ & $\begin{array}{c}\mathrm{D}=-0.0007 Q_{o p}^{2}+ \\
0.0933 Q_{o p}+1.0973\end{array}$ & 0.993 \\
\hline
\end{tabular}


한편 저류지의 최대허용수심과 방류구 직경의 관계 를 살펴보기 위해 초기 가정사항인 오리피스 방류구의 직경 $(\mathrm{D})$ 에 대한 저류지의 최대허용수심 $\left(H_{\max }\right)$ 의 관계 도를 작성하여 Fig. 5에 수록하였다. Table 5는 Fig. 5 의 관계에 대한 회귀식을 수록한 것이다.

방류구의 직경이 커짐에 따라 저류지의 최대허용수 심이 증가하고 있음을 알 수 있으며, 이는 첨두방류량 이 커짐에 따라 방류구 직경이 커지게 되고, 유입 총유 출량이 커지게 되어 저류지의 최대허용수심이 증가되는 상황을 잘 보여주고 있다.

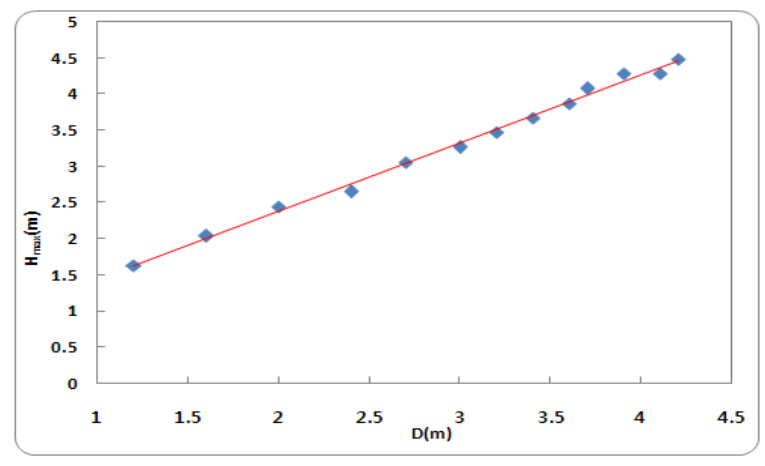

Fig. 5. Relationship between $\mathrm{D}$ and $H_{\max }$

Table 5. Relationship between $\mathrm{D}$ and $H_{\max }$

\begin{tabular}{|c|c|c|}
\hline 구 분 & 회 귀 식 & 결정계수 $\left(\mathrm{R}^{2}\right)$ \\
\hline $\begin{array}{c}\text { 방류구 직경 } \mathrm{D} \text { 에 } \\
\text { 대한 저류지 } \\
\text { 최대허용수심 } H_{\max }\end{array}$ & $H_{\max }=0.9452 \mathrm{D}+0.4899$ & 0.997 \\
\hline
\end{tabular}

방류구를 통한 방류량은 저류지의 수위에 따라 영향 을 받으므로 저류지 최대허용수심 $\left(H_{\max }\right)$ 에 대한 첨두 방류량 $Q_{o p}$ 의 관계를 Fig. 6에 수록하였다. Table 6은 Fig. 6의 관계에 대한 회귀식을 수록한 것이다.

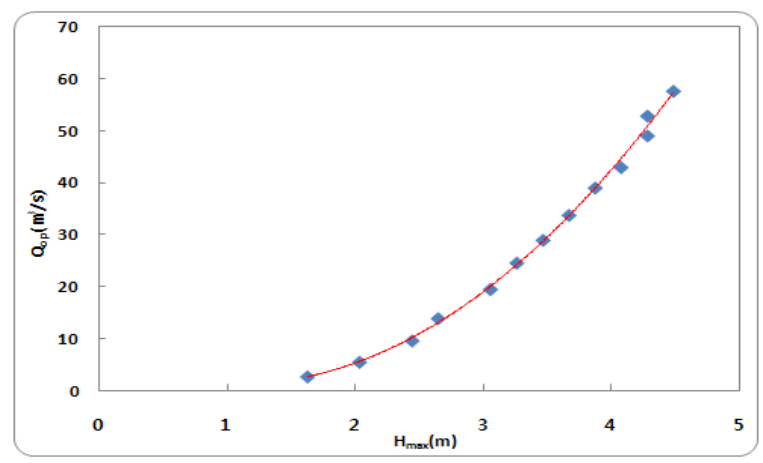

Fig. 6. Relationship between $H_{\max }$ and $Q_{o p}$
Table 6. Relationship between $H_{\max }$ and $Q_{o p}$

\begin{tabular}{|c|c|c|}
\hline 구 분 & 회 귀 식 & 결정계수 $\left(\mathrm{R}^{2}\right)$ \\
\hline 저류지 & & \\
최대허용수심 & $Q_{o p}=4.85 H_{\max }^{2}-10.6$ & 0.997 \\
$H_{\max }$ 에 대한 & $H_{\max }+7.1476$ & \\
첨두방류량 $Q_{o p}$ & & \\
\hline
\end{tabular}

2.2 .3 저류지의 구형바닥면적에 대한 제형바닥면적 관계도

일반적으로 저류용량이 주어지면 저류지의 수심과 저류지 수면적을 이용하여 직접 소요수면적을 구하거나 수심-저류용량곡선, 수심-수면적곡선, 수심-방류량곡선 등을 통하여 필요한 사항을 구할 수가 있다. 본 절에서 는 저류지를 간편설계하기 위해 필요한 그림이나 관계 식을 통해 손쉽게 저류지 바닥면적을 구할 수 있도록 단면이 구형인 저류지 구형바닥면적 $\left(\mathrm{A}^{\prime}\right)$ 과 실제 사용되 는 사다리꼴단면인 저류지 제형바닥면적(A)간의 관계 를 분석하였다. 구형바닥면적의 경우는 수심 증가에 따 라 수면적이 변하지 않으나 제형바닥면적의 경우는 수 심이 증가함에 따라 수면적이 2차 함수적으로 증가하기 때문에 간편설계시에는 먼저 구형바닥면적을 이용하는 방법을 채택하도록 유도한 것이다.

저류지의 구형바닥면적 $\mathrm{A}^{\prime}$ 에 대한 저류지의 제형바 닥면적 $\mathrm{A}$ 의 관계도를 작성하여 Fig. 7에 수록하였다. Table 7은 Fig. 7의 관계에 대한 회귀식을 수록한 것 이다.

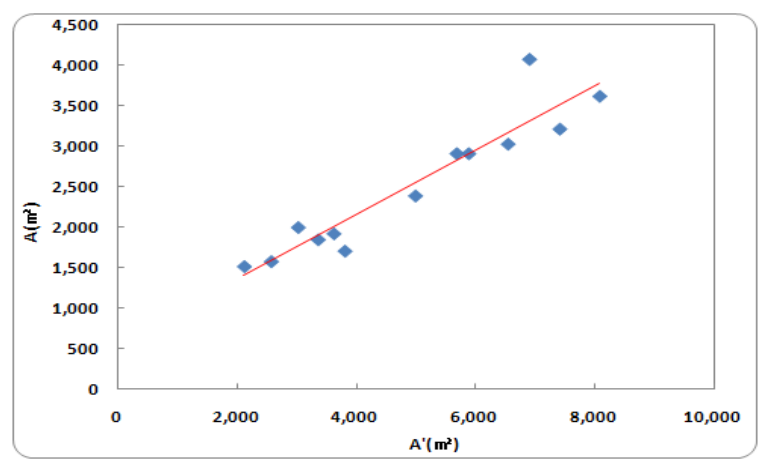

Fig. 7. Relationship between $A^{\prime}$ and $A$

Table 7. Relationship between $A^{\prime}$ and $A$

\begin{tabular}{|c|c|c|}
\hline 구 분 & 회 귀 식 & 결정계수 $\left(\mathrm{R}^{2}\right)$ \\
\hline $\begin{array}{c}\text { 저류지의 } \\
\text { 구형바닥면적 } \\
\mathrm{A}^{\prime} \text { 에 대한 } \\
\text { 제형바닥면적 } \mathrm{A}\end{array}$ & $\mathrm{A}=0.3983 \mathrm{~A}^{\prime}+556.41$ & 0.940 \\
\hline
\end{tabular}


이상에서 기술한 방법을 이용하여 저류지를 설계하 는 순서는 다음과 같다.

개발전 유입첨두유량과 개발후 유입첨두유량 및 유 출총량이 주어진 상태에서 Fig. 3을 통해 첨두유량비 $\alpha$ 로부터 저류비 $S_{r}$ 을 구하고 저류지 정의식으로부터 저류지 저류용량을 결정한다. Fig. 4를 통해 첨두방류 량(개발전 유입첨두유량) $Q_{o p}$ 로부터 방류구 직경 $\mathrm{D}$ 를 정하고 Fig. 5로부터 저류지 최대허용수심 $H_{\max }$ 을 구 한다.

이상과 같이 저류용량과 최대허용수심을 구하게 되 면 저류지의 면적을 관계식으로부터 구할 수 있으나 간 편설계를 위해 구형바닥면적으로 가정한 저류지 구형바 닥면적 $\left(\mathrm{A}^{\prime}\right)$ 을 $A^{\prime}=V_{s} / H_{\max }$ 로부터 산정하고 Fig. 6을 통해 저류지 제형바닥면적 $(\mathrm{A})$ 을 구하여 저류용량을 재 산정하면 간략화 시킴에 따른 다소간의 오차가 발생하 게 되어 보정할 필요가 있게 된다. 따라서 여기에서는 식 (1)과 같은 보정면적비(Corrected Area Ratio)를 정 의하여 저류지 보정제형바닥면적 $\left(A_{c}\right)$ 을 재산정한 후 이 를 사용하여 저류용량을 구하는 방법을 채택하였다.

보정면적비 $=A / A_{t}$

여기서, $A_{t}$ : 이론적 관계에 의해 산정된 이론제형바닥 면적

Fig. 8은 저류지 제형바닥면적과 보정면적비의 관계 를 도시한 것이고, Table 8은 Fig. 8의 관계에 대한 회 귀식을 수록한 것이다.

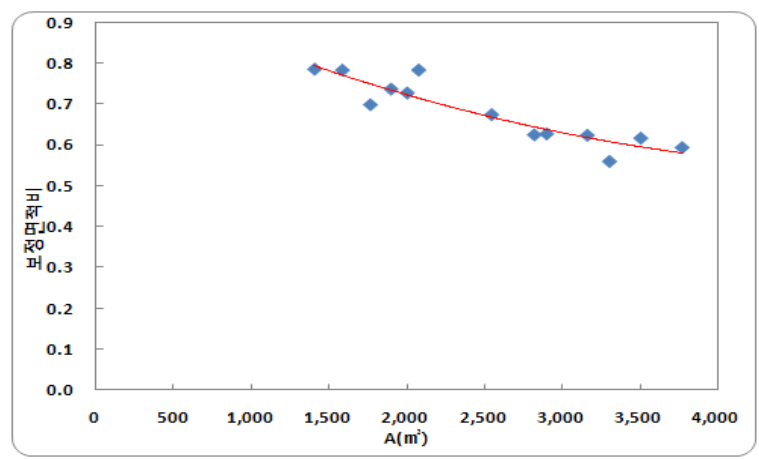

Fig. 8. Relationship between $A$ and Revision Area Ratio

Table 8. Relationship between A and Revision Area Ratio

\begin{tabular}{|c|cr|c|}
\hline 구 분 & 회 귀 식 & 결정계수 $\left(\mathrm{R}^{2}\right)$ \\
\hline $\begin{array}{c}\text { 저류지 } \\
\text { 제형바닥면적 } \mathrm{A} \text { 에 } \\
\text { 대한 보정면적비 }\end{array}$ & $\begin{array}{c}\text { 보정면적비 }=2 \mathrm{E}-08 \mathrm{~A}^{2}- \\
0.0002 \mathrm{~A}+1.0086\end{array}$ & 0.849 \\
\hline
\end{tabular}

이 때 저류지 보정제형바닥면적은 다음 식에 의해 결정된다.

저류지 보정제형 바닥면적 $\left(A_{c}\right)$

=저류지제형바닥면적 $(A) /$ 보정면적비

\section{3. 간편설계기법을 이용한 저류지의 설계절차}

본 연구에서는 저류지의 유입첨두유량에 대한 저류 지 첨두방류량의 비인 첨두유량비 $\alpha$ 와 저류지의 저류 비 $S_{r}$, 저류지의 방류구조물 직경 $\mathrm{D}$ 와 저류지의 최대 허용수심 $H_{\max }$, 저류지의 구형바닥면적 $\mathrm{A}^{\prime}$ 과 저류지의 제형바닥면적 $\mathrm{A}$ 및 $A_{c}$ 를 이용하여 저류지를 간편하게 설계하는 간편설계기법의 절차를 아래와 같이 제시하 였다.

저류지의 간편설계기법을 이용하여 저류지를 설계하 는 절차는 다음과 같다.

Step 1. : 대상지역의 강우-유출해석을 실시하여 개 발후 유입첨두유량과 유출총량 $\left(Q_{a}\right)$ 및 개발전 유입첨두 유량을 결정한 후 저류지 설계를 시작한다.

Step 2. : 다음 Eq. (3)의 저류지 개발전 유입첨두유 량(첨두방류량)과 저류지 개발후 유입첨두유량을 이용 하여 첨두유량비 $\alpha$ 를 구한다. 또는 저류지 최적계획모 형에서 산정한 저류용량이 주어진 경우에는 다음 단계 로 진행한다.

$$
\alpha=Q_{o p} / Q_{i p}
$$

여기서, $\alpha$ : 첨두유량비, $Q_{o p}$ : 개발전 유입 첨두유량 $\left(\mathrm{m}^{3} / \mathrm{s}\right), Q_{i p}$ : 개발후 유입 첨두유량 $\left(\mathrm{m}^{3} / \mathrm{s}\right)$

Step 3. : 산정된 $\alpha$ 에 대한 저류비 $S_{r}$ 을 Fig. 3 및 Table 3의 관계식을 이용하여 구한다.

Step 4. : 저류지 저류용량 $V_{s}$ 를 Eq. (4)에 의해 저 류비 $S_{r}$ 과 유입총량 $Q_{a}$ 의 곱으로 산정한다.

$$
V_{s}=S_{r} \times Q_{a}
$$

여기서, $S_{r}$ : 저류비, $V_{s}$ : 저류지 저류량 $\left(\mathrm{m}^{3}\right), Q_{a}$ : 개 발후 유입총량 $\left(\mathrm{m}^{3}\right)$

Step 5. : 개발전의 유입첨두유량(첨두방류량) $Q_{o p}$ 에 대한 방류구 직경 $\mathrm{D}$ 를 Fig. 4 및 Table 4의 관계식을 이용하여 가정한다.

Step 6. : 가정한 방류구 직경 $\mathrm{D}$ 에 대한 저류지의 최 대허용수심 $H_{\max }$ 를 Fig. 5 및 Table 5의 관계를 이용하 여 구한다.

Step 7. : Step 6에서 산정된 저류지 최대허용수심 $H_{\max }$ 에 대한 개발전 유입첨두유량(첨두방류량) $Q_{o p}$ 를 
Table 9. A Comparison between Design Model(BASINOPT) and Simplified Design Method

\begin{tabular}{|c|c|c|c|c|r|}
\hline $\begin{array}{c}\mathrm{Q}_{\mathrm{ip}} \\
\left(\mathrm{m}^{3} / \mathrm{s}\right)\end{array}$ & $\begin{array}{c}\mathrm{Q}_{\mathrm{op}} \\
\left(\mathrm{m}^{3} / \mathrm{s}\right)\end{array}$ & $\alpha$ & $\begin{array}{c}\text { BASINOPT } \\
\mathrm{V}_{\mathrm{s}}\left(\mathrm{m}^{3}\right)\end{array}$ & $\begin{array}{c}\text { 간편설계기법 } \\
\mathrm{V}_{\mathrm{s}}\left(\mathrm{m}^{3}\right)\end{array}$ & \multicolumn{1}{c|}{ 오차 $\left(\mathrm{m}^{3}\right)$} \\
\hline 3.00 & 2.79 & 0.928 & $3,462.0$ & $3,608.7$ & $-146.7(-4.24 \%)$ \\
\hline 6.00 & 5.60 & 0.934 & $6,164.6$ & $6,134.5$ & $30.2(0.48 \%)$ \\
\hline 10.00 & 9.69 & 0.969 & $6,297.8$ & $5,853.3$ & $344.5(7.06 \%)$ \\
\hline 20.00 & 19.56 & 0.978 & $10,281.0$ & $9,976.1$ & $95.0(0.80 \%)$ \\
\hline 25.00 & 24.62 & 0.985 & $11,829.7$ & $11,734.7$ & $762.0(3.53 \%)$ \\
\hline 35.00 & 33.80 & 0.966 & $21,608.3$ & $20,846.3$ & $-2,794.1(-8.06 \%)$ \\
\hline 55.00 & 52.84 & 0.961 & $34,622.6$ & $37,416.6$ & \\
\hline
\end{tabular}

Fig. 6 및 Table 6의 관계식을 이용하여 구한다.

Step 8. : Step 7에서 구해진 첨두방류량 $Q_{o p}$ 가 Step 1 의 개발전 유입첨두유량 $Q_{o p}$ 보다 작으면 다음 단 계로 넘어가고, 그렇지 않으면 Step 5로 돌아가서 방류 구 직경 $\mathrm{D}$ 를 이전단계보다 작게 재가정하여 진행한다.

Step 9. : 저류지 구형바닥면적 $\mathrm{A}^{\prime}$ 을 Eq. (5)에 의해 저류지 최대허용수심 $H_{\max }$ 에 대한 저류지 저류용량 $V_{s}$ 의 비로 구한다.

$$
A^{\prime}=V_{s} / H_{\max }
$$

여기서, $\mathrm{A}^{\prime}$ : 저류지 구형바닥면적 $\left(\mathrm{m}^{2}\right), H_{\max }$ : 저류지 최대허용수심 $(\mathrm{m})$

Step 10. : 저류지 구형바닥면적 $\mathrm{A}^{\prime}$ 에 해당하는 저 류지 제형바닥면적 A를 Fig. 7 및 Table 7을 이용하여 산정한다.

Step 11. : Step 10에서 산정된 저류지 제형바닥면 적 A는 Fig. 8 및 Table 8에 의해 보정면적비를 구한 후 Eq. (2)를 이용하여 보정제형저류지바닥면적 $\left(A_{c}\right)$ 을 구한다.

Step 12. : 보정제형저류지바닥면적 $\left(A_{c}\right)$ 과 저류지 최 대허용수심 $\left(H_{\max }\right)$ 를 이용하여 저류지 저류용량 $\left(V_{s c}\right)$ 을 산정한 후 Step 4에서 구한 저류용량 $\left(V_{s}\right)$ 과 비교하여 허용오차이내에 들면 설계를 완료하고, 그렇지 않으면 Step 5 로 되돌아가서 진행한다.

\section{4. 간편설계기법의 검증}

간편설계기법을 통한 설계결과와 저류지 설계모의모 형인 BASINOPT의 설계결과의 비교분석을 통해 간편 설계기법의 검증을 실시하였다. Table 9는 개발전 첨두 유량 $Q_{i p}$ 와 첨두유량비 $\alpha$ 에 대한 설계모의모형과 저류 지 간편설계기법을 이용한 결과를 비교한 것이다.

Table 9의 설계모의모형과 저류지 간편설계기법의 저류용량은 $30.2 \sim 2,794 \mathrm{~m}^{3}$ 범위의 오차가 나타났고, 평
균오차 $3.8 \%$ 로 설계모의모형의 저수지추적을 통한 결 과와 아주 유사하게 나타나 예비설계단계에서 충분한 적용성이 있는 것으로 판단된다.

\section{5. 결 론}

본 연구에서는 도시화로 인한 유출총량 및 첨두유량 증대에 대처하는 방안으로 유역내에 설치되는 저류지의 유역특성인자와 수문특성인자들의 관계분석을 바탕으 로 저류지 설계모의모형에서 얻어진 최적설계결과를 이 용하여 저류지 간편설계를 위한 관련변수 해석을 실시 하였다. 이 결과를 바탕으로 도시유역에서 유출저감시 설로서 시설되는 저류지를 설계함에 있어서 기존의 많 은 제반사항과 저류지 추적을 시행하지 않고 간편한 설 계를 할 수 있는 저류지의 간편설계기법을 제시하였다. 대상지역의 강우-유출해석을 실시하여 개발후 유입첨 두유량과 유출총량 $\left(Q_{a}\right)$ 및 개발전 유입첨두유량을 결정 한 후 제시된 절차대로 적용하여 간편하게 저류지를 설 계할 수 있었다. 또한 설계모의모형인 BASINOPT의 설계결과와 본 연구에서 제시한 간편설계기법 설계결과 의 비교분석에서 설계모의모형과 저류지 간편설계기법 의 저류용량은 $30.2 \sim 2,794 \mathrm{~m}^{3}$ 범위의 오차가 나타났고, 평균오차 $3.8 \%$ 로 설계모의모형의 저수지추적을 통한 결과와 아주 유사하게 나타나 간편설계기법이 예비설계 단계에서 충분한 적용성이 있는 것으로 판단되었다.

\section{감사의 글}

본 연구는 국토해양부가 출연하고 한국건설교통기술 평가원에서 위탁 시행한 2003년도 건설핵심 기술연구개 발사업(03산학연C01-01)에 의한 도시홍수재해관리기술 연구사업단의 연구성과입니다. 


\section{참 고 문 헌}

소방방재청, 한국방재협회 (2005). 재해영향평가 실 무지침서 개정.

신응배, 이두진, 곽수동, 선상운, 이동훈 (2003). “하 수관거모델을 이용한 CSO 저류시설의 최적용량 결정에 관한 연구." 한국물환경학회 - 대한상수도 학회 공동 춘계학술발표회 논문집, pp. 309 312 안태진, 박종윤, 류희정, 김중훈 (2003). "소유역에서 홍수조절용 펌프 및 유수지 규모의 결정에 관한 연구.” 한국수자원학회논문집, 한국수자원학회, 제36권, 제3호, pp. 385 398

윤여진, 이재철 (2001). "계획강우의 지속기간에 따 른 저류지용량의 산정." 한국수자원학회논문집, 한국수자원학회, 제 34 권, 제5호, pp. 415 426

이정식, 이재준, 김규호, 오석호 (1995). "도시유역에 서 지체저류시설의 수문학적 설계에 관한 연구." 한국수문학회지, 한국수문학회, 제 28 권, 제 2 호, $\mathrm{pp.}$ 159 173.

이종태, 윤세의, 이재준, 윤용남 (1991). "도시화영향 을 고려한 유수지 계획모형." 한국수문학회지, 한 국수문학회, 제 24 권, 제 4 호, pp. 73 83

이재준, 김호년, 곽창재 (2006)a. "도시화에 따른 저 류지의 유역 및 수문특성인자 분석.” 대한토목학 회 학술발표회 논문집, 대한토목학회, pp. 1141 1144

이재준, 김호년, 곽창재 (2006)b. "도시유역에서 저류 지설계를 위한 특성인자 분석." 한국방재학회논 문집, 한국방재학회, Vol. 6, No. 4, pp.37 47

이재준, 곽창재, 김호년 (2006). "도시유역에서 저류 지 계획모형의 비교 및 저류효과 분석.” 대한토목 학회 학술발표회 논문집, 대한토목학회, pp. 1053 $\sim 1056$
행정자치부(소방방재청)(2000 2006). 각종 개발사업 재해영향평가서.

환경부 (2005). 하수도 설계기준.

Abt, S.R. and N.S. Grigg (1978). "An Approximate Method for Sizing Detention Reservoirs." Water Resources Bulletin, Vol. 14, No. 4, pp. 956 965

Akan, A.O. (1993). Urban Stormwater Hydrology : A Guide to Engineering Calculations, Technomic Publishing, Lancaster, PA

Brater, E.F., King, H.W., Lindell, J.E., Wei, C.Y. (1996). "Handbook of Hydraulics, 7th ed." McGraw-hill.

Guo, Y. and B.J. Adams (1999). "An Analytical Probabilistic Approach to Sizing Flood Control Detention Facilities." Water Resources Research, Vol. 35, No. 8, pp. 2457 2468

Guo, Y. and B.J. Adams (1999). "Analysis of Detention Ponds for Storm Water Quality Control." Water Resources Research, Vol. 35, No. 8, pp. 2447 2456

Guo, Y. (2001). "Hydrologic Design of Urban Flood Control Detention Ponds." Journal of Hydrologic Engineering, Vol. 6, No. 6, pp. 472 $\sim 479$

Paine, A. (1998). "The BASINOPT Program, ver.2.7."

Wycoff, R.L. and V.P. Singh (1976). "Preliminary Hydrologic Design of Small Flood Detention Reservoirs." Water Resources Bulletin, Vol. 12, No. 2, pp. 337 349

(논문번호:08-26/접수:2008.02.22/심사완료:2008.05.06) 